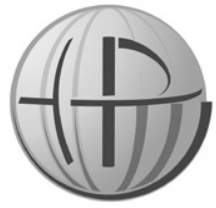

Horyzonty Polityki 2020, Vol. 11, No 37 OPEN ACCESS

\section{Izabella SteinerowsKa-Streb}

http://orcid.org/0000-0001-5379-5730 Uniwersytet Ekonomiczny w Katowicach streb@ue.katowice.pl

\section{Grzegorz GŁód}

http://orcid.org/0000-0001-9699-2427 Uniwersytet Ekonomiczny w Katowicach gglod@ue.katowice.pl

DOI: 10.35765/HP.1988

\title{
Praktyczny profil kształcenia w zakresie przedsiębiorczości na uczelniach wyższych - doświadczenia polskie a standardy międzynarodowe
}

\section{Streszczenie}

CEL NAUKOWY: Celem artykułu jest porównanie standardów praktycznego profilu kształcenia w Polsce i na zagranicznych uczelniach ekonomicznych w zakresie przyjętych celów i stosowanych metod nauczania.

PROBLEM I METODY BADAWCZE: W artykule podjęto się próby znalezienia odpowiedzi na pytanie, czy programy kształcenia realizowane $\mathrm{w}$ obszarze przedsiębiorczości na uczelniach ekonomicznych w Polsce są podobne do programów realizowanych na uczelniach zagranicznych w zakresie celów i metod kształcenia? Realizacja przyjętego celu została osiągnięta na podstawie badań jakościowych. Przedmiotem podjętego badania były cele i metody wykorzystywane na studiach pierwszego stopnia na kierunku przedsiębiorczość o profilu praktycznym. Podmiotem badania były wszystkie uczelnie w Polsce, które mają w swojej ofercie studia pierwszego stopnia na kierunku przedsiębiorczość o profilu praktycznym, oraz trzy wiodące uczelnie z podobnym programem spoza Polski. Zakres czasowy badania stanowiły lata 2019-2020, a zakres przestrzenny - cały świat.

PROCES WYWODU: Wywód składa się z dwóch zasadniczych elementów. W pierwszej, teoretycznej części artykułu zaprezentowano zasady kształcenia praktycznego w zakresie przedsiębiorczości. Następnie, w części praktycznej, przedstawiono wyniki prowadzonej analizy porównawczej.

Sugerowane cytowanie: Steinerowska-Streb, I. i Głód, G. (2020). Praktyczny profil kształcenia w zakresie przedsiębiorczości na uczelniach wyższych - doświadczenia polskie a standardy międzynarodowe. Horyzonty Polityki, 11(37), 99-116. DOI: 10.35765/HP.1988. 
WYNIKI ANALIZY NAUKOWEJ: Przeprowadza analiza wykazała, że kształcenie praktyczne w zakresie przedsiębiorczości w Polsce oraz w czołowych uczelniach zagranicznych mających w swojej ofercie studia pierwszego stopnia na kierunku przedsiębiorczość o profilu praktycznym (University of Houston, Babson College, Brigham Young University) nie różni się znacząco w zakresie celów i metod.

WNIOSKI, INNOWACJE, REKOMENDACJE: Porównanie oferty studiów pierwszego stopnia na kierunku przedsiębiorczość, które zostały stworzone przez polskie uczelnie, oraz ofert wiodących uczelni spoza Polski pozwoliło na sformułowanie rekomendacji dla polskich uczelni oferujących kształcenie w obszarze przedsiębiorczości. Rekomendacje te obejmują w szczególności propozycje dotyczące skali kształcenia - zaleca się zindywidualizowane podejście do każdego studenta. Istotne też jest, aby polskie uczelnie stworzyły studentom możliwość zdobycia praktycznego doświadczenia przykładowo poprzez współpracę z inkubatorami przedsiębiorczości.

\title{
SŁowA KLUCZOWE:
}

przedsiębiorczość, edukacja przedsiębiorczości, praktyczny profil kształcenia

\author{
Abstract \\ PRACTICAL PROFILE OF ENTREPRENEURSHIP \\ EDUCATION AT UNIVERSITIES - POLISH \\ EXPERIENCE AND INTERNATIONAL STANDARDS
}

RESEARCH OBJECTIVE: The article aims to compare standards implementation of a practical education profile in Poland and at foreign economic universities.

THE RESEARCH PROBLEM AND METHODS: The article attempts to find the answer to the question: Are education programs implemented in the field of entrepreneurship at economic universities in Poland similar to programs implemented at foreign universities in the areas of the goals and methods of education? The aim of the study was achieved on the basis of qualitative research. The subject of the study were the offers of first degree studies in the field of entrepreneurship with a practical profile. The subject of the study was all the universities in Poland that offer first-cycle entrepreneurship studies in the field of practical profile and three leading universities with similar universities outside Poland. The time range of the study was 2019-2020, and the spatial range - the whole world.

THE PROCESS OF ARGUMENTATION: Main draft process consists of two basic elements. The first part presents the principles of practical training 
in entrepreneurship. Next, the methodological assumptions of the empirical research and the results of the comparative analysis were presented.

RESEARCH RESULTS: The analysis included educational offers from the following universities: University of Houston, Babson College (Massachusetts), Brigham Young University (Utah), University of Economics in Katowice, University of Szczecin revealed that the goals and methods of education in the field of entrepreneurship do not differ significantly.

CONCLUSIONS, INNOVATIONS, AND RECOMMENDATIONS: Comparison of the offer of first degree studies in this field of entrepreneurship, which were created by Polish universities and leading universities outside of Poland, made it possible to formulate recommendations for Polish universities offering education in the field of entrepreneurship. These recommendations include, in particular, recommendations on the scale of education - an individualized approach to each student is recommended. Additionally, Polish universities should provide students an opportunity to gain practical experience, for example, through cooperation with business incubators.

\section{KeYwORDS:}

entrepreneurship, entrepreneurship education, practical education profile

\section{WSTĘP}

Przedsiębiorczość jest źródłem innowacji, zatrudnienia, wzrostu i rozwoju gospodarczego (Frederick i Kuratko, 2010). Dlatego też promowanie nauczania przedsiębiorczości stanowi jeden z najważniejszych celów polityki Unii Europejskiej i państw członkowskich. Podnoszenie wiedzy z zakresu przedsiębiorczości postrzegane jest jako niezbędne, żeby kształtować sposób myślenia uczących się, a także aby wyposażyć ich w umiejętności, wiedzę i postawy, które są potrzebne do rozwoju kultury przedsiębiorczości (Komisja Europejska, s. 9). Istotne staje się zatem, aby wysiłki podejmowane w obszarze edukacji na rzecz przedsiębiorczości były ukierunkowane na zapewnienie społeczeństwu możliwości zdobycia zindywidualizowanych i przedsiębiorczych umiejętności w kontekście podejmowania szeroko pojętych działań przedsiębiorczych (Valerio, Parton i Robb, 2014, s. 21).

Wzrost świadomości młodych ludzi w zakresie zakładania i rozwijania działalności gospodarczej, w tym tworzenia przedsiębiorstw 
społecznych, wymaga wielopłaszczyznowych działań podejmowanych na różnych szczeblach edukacji. Aby postulat ten spełnić w praktyce, musi zaistnieć synergizm programów kształcenia (edukacji formalnej) z nieformalnymi rodzajami kształcenia pozaszkolnego czy pozakademickiego. Edukacja dla przedsiębiorczości musi zatem być wspierana przez otoczenie instytucjonalne, w tym zwłaszcza przez szeroko pojętą praktykę gospodarczą (Wach, 2013, s. 251).

Problematyka dotycząca edukacji na rzecz przedsiębiorczości na poziomie szkolnictwa wyższego stała się obszarem badań, których wyniki zaprezentowano $\mathrm{w}$ niniejszym artykule. Przedmiotem tego badania były cele i metody kształcenia wykorzystywane na studiach pierwszego stopnia na kierunku przedsiębiorczość o profilu praktycznym. Celem badania było porównanie standardów realizacji praktycznego profilu kształcenia w Polsce i na zagranicznych uczelniach ekonomicznych. Realizacja tego celu została osiągnięta na podstawie badania jakościowego typu desk research. Jego rezultaty doprowadziły do znalezienia odpowiedzi na pytanie: czy programy kształcenia realizowane w obszarze przedsiębiorczości na uczelniach ekonomicznych w Polsce są podobne do programów realizowanych na uczelniach zagranicznych w zakresie celów i metod kształcenia?

\section{KSZTAŁCENIE W ZAKRESIE PRZEDSIĘBIORCZOŚCI W UCZELNI WYŻSZEJ}

Kształcenie w zakresie przedsiębiorczości na uczelniach wyższych obejmuje różnorodne działania, $\mathrm{w}$ tym formalne programy edukacji akademickiej oraz samodzielne programy szkoleniowe. Cele tych programów mogą dotyczyć rozwijania umiejętności społeczno-emocjonalnych, planowania własnej działalności biznesowej i prowadzenia spraw formalnych $\mathrm{z}$ tym związanych. W założeniu efektem tego kształcenia ma być stymulacja osób, które podejmując własną działalność gospodarcza, mogą odnieść sukces jako przedsiębiorcy. Działania te mają również doprowadzić do rozwoju przedsiębiorczości społecznej i publicznej (Matlay, Pittaway i Edwards, 2012, s. 11-12).

Treść, metody i działania wspierające tworzenie wiedzy, kompetencji i doświadczeń mają umożliwić studentom inicjowanie 
przedsięwzięć i uczestniczenie w procesach tworzenia wartości przedsiębiorczych. Tworzona wartość może mieć charakter finansowy, kulturowy lub społeczny (Lackéus, 2015, s. 11).

Istotny element $\mathrm{w}$ procesie kształcenia postaw przedsiębiorczych stanowi zdobywanie przez studentów umiejętności kreowania innowacyjnych rozwiązań. Umiejętności te mogą być bowiem dla nich użyteczne przy prowadzeniu własnego biznesu, jak i w tworzeniu środowiska sprzyjającego przedsiębiorczości korporacyjnej. Mogą z nich również skorzystać, gdyby chcieli zostać intraprzedsiębiorcami w korporacjach czy też w instytucjach publicznych (Penaluna, 2018, s. 8).

Mając na względzie wyniki badań, które wskazują że edukacja stanowi czynnik determinujący zachowania przedsiębiorcze (Steinerowska-Streb, 2018), już nauczanie samych podstaw przedsiębiorczości można uznać za szansę na wykształcenie osób lepiej przygotowanych do życia w dynamicznie zmieniającym się świecie i do odnajdywania się w różnorodnych sytuacjach, w pracy w zespole (Piróg, 2005, s. 219). Jeśli natomiast kształcenie w tym obszarze wpłynie pozytywnie na nastawienie przynajmniej części społeczeństwa do przedsiębiorczości, to intencje przedsiębiorcze w obrębie tej grupy osób wzrosna, a następstwem takiego stanu rzeczy będzie wzrost pożądanych zachowań przedsiębiorczych (Lackéus, 2015, s. 19).

Liczne badania prowadzone $\mathrm{w}$ zakresie edukacji w obszarze przedsiębiorczości (Kosała, 2016, s. 64; Głód i Raczyńska, 2018; Antoszkiewicz, 2017) wskazują na konieczność wdrażania praktycznego wymiaru kształcenia. W Polsce takie możliwości zostały stworzone na poziomie szkolnictwa wyższego przez stosowne regulacje prawne. Zgodnie z artykułem 64 pkt 2 ustawy Prawo o szkolnictwie wyższym i nauce z 20 lipca 2018 r. (Dz.U. 2018 poz. 1668) studia na polskich uczelniach mogą być prowadzone na profilu ogólnoakademickim oraz praktycznym. Na studiach o profilu praktycznym ponad połowa punktów ECTS jest przypisana zajęciom kształtującym umiejętności praktyczne. Dodatkowo program studiów o profilu praktycznym przewiduje praktyki zawodowe $w$ wymiarze co najmniej:

1. sześciu miesięcy - w przypadku studiów pierwszego stopnia i jednolitych studiów magisterskich;

2. trzech miesięcy - w przypadku studiów drugiego stopnia.

Ponadto Rozporządzenie Ministra Nauki i Szkolnictwa Wyższego z 27 września 2018 r. (Dz.U. 2018 poz. 1861) w sprawie studiów 
wskazuje w $\S 6$, że zajęcia kształtujące umiejętności praktyczne, przewidziane $\mathrm{w}$ programie studiów o profilu praktycznym, są prowadzone:

1. w warunkach właściwych dla danego zakresu działalności zawodowej;

2. w sposób umożliwiający wykonywanie czynności praktycznych przez studentów.

W świetle wskazanych regulacji prawnych istotnym warunkiem kształcenia jest zatem stworzenie środowiska edukacyjnego, które odwzoruje w jak największym stopniu środowisko biznesowe.

\section{METODA BADAWCZA}

Realizacja przyjętego celu została osiągnięta na podstawie badań jakościowych. Przedmiotem podjętego badania były cele i metody kształcenia wykorzystywane na studiach pierwszego stopnia na kierunku przedsiębiorczość o profilu praktycznym. Podmiotem badania były wszystkie uczelnie w Polsce, które mają w swojej ofercie studia pierwszego stopnia na kierunku przedsiębiorczość o profilu praktycznym, oraz trzy wiodące uczelnie o podobnej uczelni spoza Polski. Zakres czasowy badania stanowiły lata 2019-2020, a zakres przestrzenny - cały świat.

Wąsko określone pytanie badawcze przesądziło o zaliczeniu projektu badawczego do tzw. ścisłych, zgodnie z wytycznymi dotyczącymi klasyfikacji badań jakościowych według Milesa i Hubermana. Stosownie do powszechnie obowiązujących wymogów w tego typu badaniach dobór próby miał charakter sformalizowany i był posłuszny logice generalizacji (Flick, 2012, s. 56). Mając na względzie stworzenie bazy uczelni, które będą stanowić zbiór empirycznych przykładów umożliwiających jak najbardziej dogłębną eksplorację tematu, w podjętym postępowaniu badawczym przyjęto, że do badania zostaną zaklasyfikowane wszystkie uczelnie w Polsce, które mają w swojej ofercie studiów pierwszego stopnia kierunek przedsiębiorczość o profilu praktycznym, oraz trzy wiodące uczelnie prowadzące tego typu kierunki zagranicą.

W pierwszym etapie podjętych badań dokonano identyfikacji polskich uczelni oferujących kierunek przedsiębiorczość o profilu 
praktycznym na podstawie informacji zawartych na portalu Studia (studia.gov.pl) oraz Otouczelnie (otouczelnie.pl). Portale te prezentują wiadomości na temat kierunków studiów, które znajdują się w ofercie szkół wyższych w Polsce. Na tej podstawie rozpoznano, że polskie uczelnie oferują następujące kierunki studiów pierwszego stopnia dotyczące przedsiębiorczości:

- Przedsiębiorczość - 1 uniwersytet (Uniwersytet Śląski),

- Przedsiębiorczość i finanse - 1 uniwersytet (Uniwersytet Ekonomiczny w Katowicach),

- Przedsiębiorczość i inwestycje - 1 uniwersytet (Uniwersytet Szczeciński),

- Przedsiębiorczość i zarządzanie innowacjami - 1 uniwersytet (Uniwersytet Łódzki).

Weryfikacja ofert uniwersytetów doprowadziła do wyselekcjonowania wśród nich tylko tych, które oferują kierunki o profilu praktycznym - Uniwersytetu Ekonomicznego w Katowicach oraz Uniwersytetu Szczecińskiego.

W dalszej części postępowania badawczego dokonano rozpoznania wiodących uczelni na świecie, które mają w swojej ofercie studiów pierwszego stopnia kierunek przedsiębiorczość. W tym celu skorzystano z 14. corocznego rankingu Princeton Review (2019), w którym identyfikuje się czołowe szkoły wyższe oferujące kształcenie na kierunku przedsiębiorczość. Ranking ten dotyczy 40 różnych obszarów obejmujących m.in. odsetek wykładowców, studentów i absolwentów, którzy aktywnie i skutecznie angażowali się w przedsięwzięcia z zakresu przedsiębiorczości; liczbę i zakres programów mentorskich, stypendia i dotacje na studia z zakresu przedsiębiorczości; poziom wsparcia dla sponsorowania przez uczelnię konkursów na biznesplany. W rankingu sporządzonym w $2019 \mathrm{r}$. zostały wytypowane uczelnie, które uznano za wiodące w $2020 \mathrm{r}$. W pierwszej dziesiątce tych uniwersytetów znalazły się (The Princeton Review, 2019):

1. University of Houston

2. Babson College (Massachusetts)

3. Brigham Young University (Utah)

4. The University of Michigan

5. Baylor University

6. Washington University in St. Louis

7. University of Maryland 
8. Tecnológico de Monterrey (Mexico)

9. Northeastern University (Massachusetts)

10. North Carolina State University

Stosownie do przyjętych założeń z powyższej listy wybrano trzy pierwsze uczelnie: University of Houston, Babson College (Massachusetts) i Brigham Young University (Utah). Ofertę wskazanych uczelni porównano z ofertą Uniwersytetu Ekonomicznego w Katowicach i Uniwersytetu Szczecińskiego.

\section{ANALIZA OFERTY NA STUDIACH PIERWSZEGO STOPNIA NA KIERUNKU PRZEDSIĘBIORCZOŚĆ NA WYBRANYCH UCZELNIACH W POLSCE I ZAGRANICA}

Kształcenie studentów na studiach pierwszego stopnia na kierunku przedsiębiorczość i finanse znajdujących się w ofercie Uniwersytetu Ekonomicznego w Katowicach ukierunkowane jest na rozwój kompetencji potrzebnych menedżerom $\mathrm{w}$ małym i średnim biznesie. Kierunek ten dostarcza studentom kompleksowej wiedzy w zakresie zarządzania, finansów, prawa, podatków, księgowości, negocjacji, technik pracy menedżera, marketingu, spraw kadrowo-płacowych, potrzebnej do uruchamiania i prowadzenia działalności gospodarczej. Podczas studiów studenci nabywają także praktyczne umiejętności niezbędne, aby stworzyć własną firmę (start-up) i ją rozwijać. Studenci uczeni są także, jak przygotować firmę rodzinną do sukcesji oraz jak skutecznie kierować różnymi przedsięwzięciami. Po ukończeniu studiów są oni również gotowi do podjęcia pracy w różnych obszarach funkcjonowania małych i średnich przedsiębiorstw o dowolnym profilu.

Na studiach pierwszego stopnia główne wyróżniki w zakresie nauczania na kierunku przedsiębiorczość i finanse to:

- zajęcia prowadzone są z wykorzystaniem różnorodnych metod, takich jak wykład, analiza przypadków, ćwiczenia z wykorzystaniem nowoczesnego oprogramowania informatycznego;

- aktywizujące formy pracy ze studentami, jak np. dyskusja, burza mózgów, opracowanie projektów, prezentacji (również w grupach), uczenie się przez wejście w rolę; 
- samodzielna realizacja przez studenta projektu przez kolejne cztery semestry studiów; student wybiera albo projekt (1) „Zakładanie działalności gospodarczej”, albo (2) „Rozwiązywanie problemu w realnie funkcjonującej firmie";

- praktyka zawodowa trwa sześć miesięcy;

- zajęcia prowadzone przez pracowników naukowych w większości posiadających doświadczenie praktyczne oraz przez przedstawicieli praktyki gospodarczej.

Absolwenci pierwszego stopnia kierunku przedsiębiorczość i finanse mogą zatem uruchomić własną firmę oraz zarządzać nią. Są oni również przygotowani do pracy na stanowiskach kierowniczych $\mathrm{w}$ różnych obszarach zarządzania firmą jako specjaliści z zakresu finansów, kadr, rachunkowości, obsługi klienta, ICT, e-biznesu; uczestnicy zespołów projektowych lub zadaniowych; absolwent może podjąć pracę $\mathrm{w}$ małych i średnich przedsiębiorstwach o różnym profilu działalności oraz innych organizacjach.

Kierunek przedsiębiorczość i inwestycje, który oferowany jest przez Uniwersytet Szczeciński, ma na celu przekazanie studentom wiedzy z zakresu ekonomii, nauk o zarządzaniu i pokrewnych dyscyplin naukowych oraz rozwijanie ich umiejętności praktycznych dotyczących prowadzenia małego przedsiębiorstwa, rozwijania biznesu rodzinnego oraz rozwijania kariery lokalnego lidera - kreatora przedsięwzięć gospodarczych i inicjatyw w lokalnej społeczności. Po ukończeniu studiów na tym kierunku student powinien (Uniwersytet Szczeciński):

- krytycznie analizować zjawiska i procesy ekonomiczne zachodzące w małych i średnich przedsiębiorstwach;

- posługiwać się metodami i technikami niezbędnymi do rozwiązywania problemów i podejmowania decyzji w przedsiębiorstwie z wykorzystywaniem instrumentów, metod, narzędzi analitycznych i organizatorskich;

- realizować własne pomysły biznesowe w formie małej firmy;

- zakładać oraz prowadzić własną działalność gospodarczą w skali lokalnej, krajowej lub międzynarodowej.

Po otrzymaniu tytułu zawodowego licencjata absolwent ma być przygotowany do (Uniwersytet Szczeciński):

- założenia i rozwijania własnego biznesu;

- przejęcia biznesu rodzinnego; 
- pracy na stanowiskach kierowniczych i specjalistycznych w małych i średnich przedsiębiorstwach, w firmach konsultingowych i innych organizacjach typu instytucje wspierania przedsiębiorczości;

- odgrywania roli lidera przedsiębiorczości lokalnej np. na wsi, w małej miejscowości.

Kierunek ten jest realizowany we współpracy z przedsiębiorcami i lokalnymi instytucjami wspierania biznesu, dzięki czemu kształcenie studentów jest ukierunkowane na oczekiwania pracodawców. Podczas zajęć teorię łączy się z praktyką. Organizuje się spotkania z przedsiębiorcami, angażuje studentów w gry decyzyjne, a także analizuje case studies. Studenci mają ponadto możliwość skorzystania z doświadczenia praktyków biznesu oraz poznania praktyki gospodarczej dzięki licznym wizytom w małych i średnich firmach(Uniwersytet Szczeciński).

Uniwersytet w Houston (University of Houston) ma w swojej ofercie kierunek przedsiębiorczość (ENTR), który jest skierowany do studentów planujących otworzyć lub rozwinąć własną działalność gospodarczą (University of Houston). Nauczanie na tym kierunku jest prowadzone przez specjalistów Wolff Center for Entrepreneurship (WCE), którzy zapraszają na swoje zajęcia doświadczonych przedsiębiorców, aby zaznajomić studentów z praktyką gospodarczą.

Na kierunek przedsiębiorczość studenci są przyjmowani dopiero po spełnieniu ściśle określonych kryteriów rekrutacyjnych. Na początku osoby aplikujące muszą zostać przyjęte na kierunki biznesowe oferowane na Uniwersytecie w Houston przez Bauer College of Business. Następnie kandydaci na kierunek przedsiębiorczość przechodzą proces rygorystycznej selekcji i spośród aplikantów zostają wybrane osoby, które będą mogły uczęszczać na studia pozwalające im na uzyskanie tytułu licencjata w zakresie przedsiębiorczości (BBA in Entrepreneurship).

Cykl nauczania na kierunku przedsiębiorczość obejmuje sześć kursów realizowanych w trakcie trzy- lub czterosemestralnego programu nauczania, który obejmuje sześć kursów: (1) wprowadzenie do przedsiębiorczości, (2) przychody przedsiębiorcy, (3) koszty i budżet przedsiębiorcy, (4) organizacje przedsiębiorcze, kapitalizacja i finansowanie, (5) biznesplan i (6) wdrożenie biznesplanu. Nadprogramowo studenci moga przejść kurs z przedsiębiorczości 
korporacyjnej. Umożliwi im to uzyskanie dodatkowego certyfikatu z intraprzedsiębiorczości (University of Houston).

Każdego roku na kierunek przedsiębiorczość przyjmowanych jest jedynie 35-45 osób (Bauer College of Business). Podczas studiów studenci tworzą i systematycznie doskonalą swój pomysł na biznes. W trakcie przygotowania projektów mogą korzystać ze wsparcia kadry akademickiej oraz omawiać pojawiające się problemy w dyskusjach z rówieśnikami i wykładowcami przy tzw. okrągłym stole. $\mathrm{Z}$ założenia każdy student tego kierunku ma umieć przekształcić swoją pasję w biznes. Mają mu w tym pomóc umiejętności zdobyte $\mathrm{w}$ trakcie kształcenia. $Z$ danych uniwersytetu wynika, że ponad $50 \%$ studentów kończących ten kierunek zakłada firmy, a inni są poszukiwanymi przez pracodawców pracownikami zorientowanymi na przedsiębiorczość (University of Houston).

Tymczasem w Babson College program nauczania na kierunku przedsiębiorczość (Entrepreneurship) zawiera elementy podstaw biznesu oraz socjologii. Wiedza zdobyta przez studentów podczas obowiązkowych i dodatkowych kursów ma im pomóc w rozpoznawaniu szans rynkowych i pozyskiwaniu niezbędnych zasobów. Po zakończeniu studiów studenci mają umieć samodzielnie wykonać analizę finansowa, tworzyć zespoły, budować modele biznesowe, prowadzić rozmowy z partnerami biznesowymi i klientami, ocenić wykonalność projektów, a także rozpocząć nowe przedsięwzięcie. Umiejętności i kompetencje zdobyte na kierunku przedsiębiorczość umożliwiają absolwentom otwarcie firmy, lub też innej organizacji, a w szczególności start-upu, dużego przedsiębiorstwa, firmy rodzinnej, organizacji nonprofit, firmy działającej na zasadach franchisingu. Stosownie do potrzeb studenci mogą zdobyć specjalistyczną wiedzę w zakresie handlu detalicznego lub usług, technologii, funkcjonowania organizacji nonprofit, firm rodzinnych, globalnych lub w przedsiębiorczości korporacyjnej (Babson College).

Swoje zainteresowania studenci mogą poszerzać dzięki uczestnictwu w kursach z "Rozwiązywania dużych problemów”, "Projektowania i przedsiębiorczości”, ,Crowdfoundingu”, ,Technologii ochrony środowiska”, „Platform, chmur i sieci”, „Analizy biznesowej i analizy danych", "Strategii handlu finansowego i zarządzania ryzykiem". Podczas wszystkich tych zajęć studenci zachęcani są do 
dyskusji i krytycznego myślenia w celu rozwijania ich zdolności przywódczych, generowania pomysłów i pracy zespołowej.

Już podczas pierwszego roku studiów studenci mają się nauczyć tworzyć, rozwijać, uruchamiać prawdziwe przedsięwzięcie i wiedzieć, jak nim zarządzać. W tym celu Babson College stworzył specjalną Fundację Zarządzania i Przedsiębiorczości (Foundations of Management and Entrepreneurship, FME), która udostępnia celowo utworzonym zespołom środki finansowe na otwarcie dowolnego przedsięwzięcia. Na początku studenci zdobywają podstawową wiedzę z przedsiębiorczości, marketingu, rachunkowości, zachowań organizacyjnych, systemów informatycznych i operacji. Następnie, w grupach liczących około 40 studentów, powstają trzy zespoły, a College pożycza każdemu z nich do 9000 USD na założenie firmy. Pomysły na biznes są dowolne. Ważne jest, aby studenci zastanowili się, w jaki sposób ich firma spełnia ludzkie potrzeby. Dzięki temu studenci zdobywają praktyczne doświadczenie. Uczą się, jak prowadzić biznes, jak się komunikować, pracować w zespole i pokonywać przeszkody (Babson College).

W ostatnim z analizowanych uniwersytetów - Uniwersytecie w Brigham (Brigham Young University, Utah) - nauczanie na kierunku przedsiębiorcze zarządzanie (Entrepreneurial management) ma na celu rozwój umiejętności studentów w zakresie założenia przedsiębiorstwa, a w szczególności start-upu. Ponadto studenci mają być przygotowani do prowadzenia przedsiębiorstwa, a także do bycia przedsiębiorcą korporacyjnym.

Podczas studiów studenci zdobywają wiedzę, rozwiązując praktyczne zadania, tworząc projekty, analizując praktyczne studia przypadków i prowadząc wspólne dyskusje. W programie kładzie się nacisk na rozwój umiejętności z zakresu zarządzania firmą od start-upu do firmy o ugruntowanej pozycji, a także na znajomość zasad rozwoju firmy i rozwoju produktu oraz na rozumienie istoty podstawowych funkcji biznesowych.

$\mathrm{Na}$ kierunek przedsiębiorczość rekrutuje się rocznie 40 studentów. Nauka trwa trzy lub cztery semestry, a studenci są zachęcani do zdobycia 12-15 punktów ECTS w każdym semestrze. Podstawowy program obejmuje: przedsiębiorczość innowacyjna, strategię i ekonomię, rozwój kariery, tworzenie nowych przedsięwzięć, zagadnienia prawne w zakresie przedsiębiorczości i przedsiębiorczość 
eksperymentalną. Ponadto, studenci wybierają dodatkowe kursy w zależności od indywidualnych preferencji (Brigham Young University).

PODOBIEŃSTWA I RÓŻNICE W CELACH

I METODACH KSZTAŁCENIA NA KIERUNKU

PRZEDSIĘBIORCZOŚĆ NA WYBRANYCH

UCZELNIACH W POLSCE I ZAGRANICA

Analiza informacji dotyczących kształcenia studentów pierwszego stopnia na kierunku przedsiębiorczość o profilu praktycznym na wybranych uczelniach wyższych w Polsce i zagranicą wskazuje, że na wszystkich badanych uczelniach głównym celem nauczania jest dostarczenie studentom wiedzy, która ułatwi im rozpoczęcie działalności gospodarczej lub zainicjowanie innego przedsięwzięcia (tabela 1).

We wszystkich badanych uczelniach teorię łączy się z praktyką. Wszędzie stosuje się aktywizujące formy pracy ze studentami, a w szczególności rozpatruje się praktyczne studia przypadków. Niemniej jednak pomiędzy analizowanymi uczelniami pojawiają się pewne różnice w obrębie stosowanych metod nauczania. W jednych uczelniach organizuje się wizyty studyjne w przedsiębiorstwach, $\mathrm{w}$ innych zaprasza się przedsiębiorców na spotkania, podczas których dzielą się oni swoją wiedzą i doświadczeniami. W przeciwieństwie do pozostałych badanych uczelni, jedynie Babson College umożliwia studentom zdobycie wiedzy poprzez uruchomienie prawdziwego przedsiębiorstwa z wykorzystaniem środków finansowych specjalnie w tym celu założonej fundacji (tabela 2). 
Tabela 1

Cel ksztatcenia studentów na kierunku przedsiębiorczość o profilu praktycznym na wybranych uczelniach wyższych w Polsce i zagranica

\begin{tabular}{|c|c|}
\hline Uniwersytet & Cel kształcenia \\
\hline $\begin{array}{l}\text { Uniwersytet Ekonomiczny } \\
\text { w Katowicach }\end{array}$ & $\begin{array}{l}\text { - dostarczenie wiedzy i umiejętności praktycznych } \\
\text { potrzebnych do uruchamiania i prowadzenia } \\
\text { działalności gospodarczej } \\
\text { przygotowanie studentów do podjęcia pracy } \\
\text { w różnych obszarach funkcjonowania małych } \\
\text { i średnich przedsiębiorstw o dowolnym profilu }\end{array}$ \\
\hline Uniwersytet Szczeciński & $\begin{array}{l}\text { - dostarczenie wiedzy i rozwijanie umiejętności } \\
\text { praktycznych dotyczących prowadzenia małego } \\
\text { przedsiębiorstwa, rozwijania biznesu rodzinnego } \\
\text { oraz rozwijania kariery lokalnego lidera - } \\
\text { kreatora przedsięwzięć gospodarczych i inicjatyw } \\
\text { w lokalnej społeczności }\end{array}$ \\
\hline $\begin{array}{l}\text { Uniwersytet w Houston } \\
\text { (University of Houston) }\end{array}$ & $\begin{array}{l}\text { - dostarczenie wiedzy i rozwijanie umiejętności } \\
\text { potrzebnych, aby otworzyć lub rozwinąć własną } \\
\text { działalność gospodarczą } \\
\text { dodatkowym celem jest nabycie przez studentów } \\
\text { umiejętności z zakresu przedsiębiorczości } \\
\text { korporacyjnej }\end{array}$ \\
\hline Babson College & $\begin{array}{l}\text { - zdobyte umiejętności i kompetencje mają } \\
\text { umożliwić absolwentom otwarcie firmy } \\
\text { lub też innej organizacji (start-upu, dużego } \\
\text { przedsiębiorstwa, firmy rodzinnej, organizacji } \\
\text { nonprofit, firmy działającej na zasadach } \\
\text { franchisingu) } \\
\text { studenci mogą się wyspecjalizować w handlu } \\
\text { detalicznym lub usługach, technologii, } \\
\text { organizacjach nonprofit, firmach rodzinnych, } \\
\text { globalnych lub w przedsiębiorczości korporacyjnej }\end{array}$ \\
\hline $\begin{array}{l}\text { Uniwersytet w Brigham } \\
\text { (Brigham Young University) }\end{array}$ & 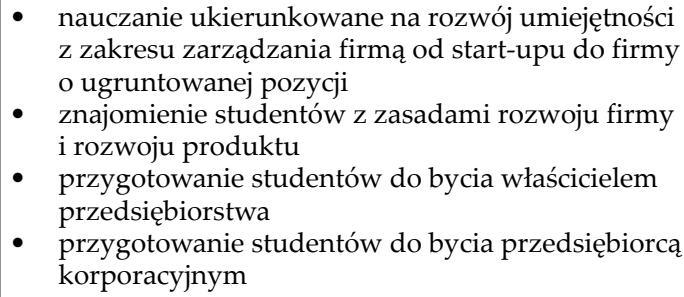 \\
\hline
\end{tabular}

Źródło: opracowanie własne. 
Tabela 2

Podstawowe metody ksztatcenia studentów na kierunku przedsiębiorczość o profilu praktycznym na wybranych uczelniach wyższych w Polsce i zagranica

\begin{tabular}{|c|c|}
\hline Uniwersytet & Metody kształcenia \\
\hline $\begin{array}{l}\text { Uniwersytet } \\
\text { Ekonomiczny } \\
\text { w Katowicach }\end{array}$ & $\begin{array}{l}\text { - } \quad \text { ćwaliza studiów przypadku } \\
\text { - aprogramowania informatycznego } \\
\text { aktywizujące formy pracy ze studentami, jak np. dyskusja, } \\
\text { burza mózgów, opracowanie projektów, prezentacji (również } \\
\text { w grupach), uczenie się przez wejście w rolę } \\
\text { - } \quad \text { samodzielna realizacja przez studenta projektu przez } \\
\text { kolejne cztery semestry studiów; student wybiera albo } \\
\text { projekt (1) "Zakładanie działalności gospodarczej”, } \\
\text { albo (2) „Rozwiązywanie problemu w realnie funkcjonującej } \\
\text { firmie”; } \\
\text { zajęcia prowadzone przez pracowników naukowych } \\
\text { w większości posiadających doświadczenie praktyczne oraz } \\
\text { przez przedstawicieli praktyki gospodarczej }\end{array}$ \\
\hline $\begin{array}{l}\text { Uniwersytet } \\
\text { Szczeciński }\end{array}$ & $\begin{array}{l}\text { - } \quad \text { organizuje się spotkania z przedsiębiorcami } \\
\text { - } \quad \text { praca w małych zespołach, } \\
\text { - } \quad \text { studenci tworzą autorskie projekty } \\
\text { - } \quad \text { angażuje się studentów w gry decyzyjne } \\
\text { - } \quad \text { analizuje się casestudies } \\
\text { studencisą uczestnikami wizyt w małych i średnich firmach }\end{array}$ \\
\hline $\begin{array}{l}\text { Uniwersytet } \\
\text { w Houston } \\
\text { (University } \\
\text { of Houston) }\end{array}$ & $\begin{array}{l}\text { - } \quad \text { na zajęcia zapraszani są doświadczeni przedsiębiorcy } \\
\text { - } \quad \text { podczas studiów studenci tworzą i systematycznie doskonalą } \\
\text { swój pomysł na biznes } \\
\text { - } \quad \text { omawianie problemów w dyskusjach z rówieśnikami } \\
\text { i wykładowcami przy tzw. okrągłym stole } \\
\text { - zajęcia prowadzone przez doświadczonych specjalistów }\end{array}$ \\
\hline Babson College & $\begin{array}{l}\text { - } \quad \text { podczas zajęć studenci zachęcani są do dyskusji } \\
\text { i krytycznego myślenia } \\
\text { - ćwiczenia rozwijające zdolności przywódcze, generowanie } \\
\text { pomysłów i umiejętnośc pracy zespołowej } \\
\text { - } \\
\text { studenci w zespołach zakładają dowolną prawdziwą firmę, } \\
\text { korzystając ze środków finansowych specjalnej fundacji } \\
\text { stworzonej na uczelni }\end{array}$ \\
\hline $\begin{array}{l}\text { Uniwersytet } \\
\text { w Brigham } \\
\text { (Brigham } \\
\text { Young } \\
\text { University) }\end{array}$ & $\begin{array}{l}\text { - } \quad \text { rozwiązywania praktycznych zadań } \\
\text { - } \quad \text { pojorzenie innowacyjnych rozwiązań problemów } \\
\text { - } \quad \text { tworzenie projektów praktyce gospodarczej } \\
\text { - } \quad \text { analiza casestudies } \\
\text { - dyskusja }\end{array}$ \\
\hline
\end{tabular}

Źródło: opracowanie własne.

Analiza informacji dotyczących kształcenia studentów pierwszego stopnia na kierunku przedsiębiorczość o profilu praktycznym na 
wybranych uczelniach wyższych w Polsce i zagranicą wskazuje, że założenia stojące $u$ podstaw tego kształcenia są zbliżone. Nauczanie na kierunku przedsiębiorczość ma przede wszystkim rozwinąć kompetencje i umiejętności w kierunku prowadzania własnej działalności gospodarczej bądź alternatywnie w przyszłości pracy menedżera w organizacji.

\section{PODSUMOWANIE}

W artykule zaprezentowano wyniki badania jakościowego dotyczącego studiów o profilu praktycznym na kierunku przedsiębiorczość. Porównanie polskich uczelni oraz trzech wiodących uczelni spoza Polski oferujących studia pierwszego stopnia na tym kierunku wykazało, że cele tych studiów i metody kształcenia stosowane do ich osiągnięcia są w obrębie tych uczelni w zasadniczej części podobne.

Wyniki przeprowadzonej analizy zainspirowały jej autorów do zaproponowania kilku rekomendacji dla polskich uczelni oferujących kształcenie w obszarze przedsiębiorczości. Istotne wydaje się, aby polskie uczelnie wyższe $\mathrm{w}$ przyszłości stworzyły studentom możliwość prowadzenia własnej działalności gospodarczej (przykładowo $\mathrm{w}$ inkubatorze przedsiębiorczości lub $\mathrm{w}$ formie projektu edukacyjnego). Należy też utrzymywać, aby studia o profilu praktycznym na kierunku przedsiębiorczość nie były masowe. Tego typu nauczanie nie umożliwia bowiem zastosowania zindywidualizowanego podejścia do każdego studenta.

Ponadto, w procesie nauczania należy rozwijać wątki związane z przedsiębiorczością społeczną i publiczną. Ważne jest także, aby akcentować kwestię rozwoju przedsiębiorczości korporacyjnej oraz pobudzać w studentach chęć do występowania w roli intraprzedsiębiorcy. $Z$ tej perspektywy za pozytywne można uznać, że oba wskazane wątki są rozwijane już obecnie w trakcie studiów na kierunku przedsiębiorczość na Uniwersytecie Ekonomicznym w Katowicach. 


\section{BibLIOGRAFIA}

Pozycje zwarte

Flick, U. (2012). Projektowanie badania jakościowego. Warszawa: Wydawnictwo Naukowe PWN.

Komisja Europejska/EACEA/Eurydice, 2016. Entrepreneurship Education at School in Europe. (Nauczanie przedsiębiorczości w szkołach w Europie). Raport Eurydice. Luksemburg: Urząd Publikacji Unii Europejskiej.

Penaluna, A. (2018). Enterprise and entrepreneurship education: Guidance for UK higher education providers. British Quality Assurance Agency for Higher Education (QAA).

Artykuły

Antoszkiewicz, J.D. (2017). Akademicki trening przedsiębiorczości. Zeszyty Naukowe Politechniki Poznańskiej. Organizacja i Zarzadzanie, 75, 25-33.

Głód, G. i Raczyńska, E. (2018). Analiza projektu „Rozwiązanie problemu w realnie funkcjonującej firmie" $\mathrm{w}$ ramach praktycznego profilu studiów „Przedsiębiorczość i Finanse”. Horyzonty Wychowania, 17(44), 199-208.

Kosala, M. (2016). Edukacja przedsiębiorczości-analiza tendencji, metod i narzędzi w zakresie nauczania przedsiębiorczości w środowisku akademickim. Horyzonty Wychowania, 15(34), 49-66.

Lackéus, M. (2015). Entrepreneurship in education: What, why, when, how. Enterpreneurship 360 Background Paper, OECD.

Matlay, H., Pittaway, L. Edwards, C. (2012). Assessment: examining practice in entrepreneurship education. Education+ Training, 54(8/9), 778-800.

Piróg, D. (2005). Miejsce i rola edukacji europejskiej w nauczaniu podstaw przedsiębiorczości w kontekście współczesnych wyzwań cywilizacyjnych. Przedsiębiorczość-Edukacja, 1, 213-220.

Steinerowska-Streb, I. (2018). Edukacja a zachowania przedsiębiorcze właścicieli-menedżerów zarządzających przedsiębiorstwami rodzinnymi. Horyzonty Wychowania, 17 (41), 237-250.

Wach, K. (2013). Edukacja na rzecz przedsiębiorczości wobec współczesnych wyzwań cywilizacyjno-gospodarczych. Przedsiębiorczość-Edukacja, 9, 246-257. 
Strony WWW i akty prawne

Babson College (2020). Undergraduate Curriculum and Courses. Pozyskano z: https://www.babson.edu/academics/undergraduate-school/ curriculum/ (dostęp:02.03.2020).

Bauer College of Business (2020). BBA in Entrepreneurship. Pozyskano z: https://www.bauer.uh.edu/undergraduate/entrepreneurship/ (dostęp: 02.03.2020).

Brigham Young University (2020).Program Overview. Pozyskano z: https://marriottschool.byu.edu/ent/academics/what-will-i-study/ overview/ (dostęp: 02.03.2020).

Rozporządzenie Ministra Nauki i Szkolnictwa Wyższego z dnia 27 września 2018 roku (Dz.U. 2018 poz. 1861)

The Princeton Review (2019).Top Schools for Entrepreneurship Studies 2020 Press Release. Pozyskano z:https://www.princetonreview.com/press/ top-entrepreneurial-press-release (dostęp: 01.03.2020).

University of Houston (2020). BBA in Entrepreneurship(within the Wolff Center for Entrepreneurship. Pozyskano z: https://www.bauer.uh.edu/undergraduate/documents/BBAinEntrepreneurship_2010. pdf (dostęp: 01.03.2020).

Uniwersytet Szczeciński (2020). Przedsiębiorczość i inwestycje - studia stacjonarne. Pozyskano z: https://efz.usz.edu.pl/ksztalcenie/kierunki-studiow-stacjonarne/przedsiebiorczosc-i-inwestycje (dostęp: 01.03.2020).

Ustawa Prawo o szkolnictwie wyższym i nauce z dnia 20 lipca 2018 roku (Dz. U. 2018 poz. 1668).

\section{Copyright and License}

This article is published under the terms of the Creative Commons Attribution - NoDerivs (CC BY- ND 4.0) License http://creativecommons.org/licenses/by-nd/4.0/ 